\title{
Development of Bra Pressure Measuring System Using Air Pressure Sensor
}
Desarrollo de la presión del sujetador. Sistema de medición con aire y sensor de presión

\author{
Desenvolvimento da pressão do sutiã. Sistema de medição \\ com ar e sensor de pressão
}

\author{
Hong Nhung Luu Thi ${ }^{1}$ \\ Trinh Nguyen Nhat ${ }^{2}$ \\ Linh Nguyen Thi Dieu ${ }^{3}$ \\ Le Nguyen Thi ${ }^{4}$
}

Received: September $25^{\text {th }}, 2019$

Accepted: November $17^{\text {th }}, 2019$

Available: January $31^{\text {th }}, 2020$

How to cite this article:

H. N. Luu Thi, T. Nguyen Nhat, L. N. Thi Dieu and L. Thi, "Development of Bra Pressure Measuring System Using Air Pressure Sensor," Revista Ingeniería Solidaria, vol. 16, no. 1, 2020. doi: https://doi.org/10.16925/2357-6014.2020.01.04

Artículo de investigación. https://doi.org/10.16925/2357-6014.2020.01.04

1 Department of sewing technology. Faculty of Garment Technology. Hung Yen University of Technology and Education.

E-mail: nhung.luuhong.hust@gmail.com

ORCID: https://orcid.org/0000-0002-6710-3931

2 Shool of Textile - Leather and Fashion, Ha Noi University of Science and Technology.

E-mail: trinh.nguyennhat@hust.edu.vn

ORCID: https://orcid.org/0000-0002-2014-7988

3 Faculty of Electronics Engineering Technology, Hanoi University of Industry.

E-mail: dieulinh79@gmail.com

ORCID: https://orcid.org/0000-0001-8596-392X

4 Faculty of Garment Technology and Fashion Design, Hanoi University of Industry.

E-mail: le.nguyenthi@haui.edu.vn.

ORCID: https://orcid.org/0000-0002-2302-0309 


\section{Abstract}

Introduction: This paper is the result of the research "Development of bra pressure measuring system using air pressure sensor" developed in the Ha Noi University of Science and Technology in 2019.

Problem: The pressure of the bra on the human body affects the comfort of the wearer and the wearer's health. Therefore, bra pressure is one of the most important parameters taken into account when designing and manufacturing bras.

Objective: To determine the pressure value of a bra, it is necessary to use a suitable pressure measuring device.

Methodology: The device operates on the principle of resitive gas pressure sensor, with 8 measuring channels. The system is controlled by the computer via programming software in the Visual $C$ language, measuring the pressure of the shirt on the position on the curved surface of the human body. Pressure values and timed charts are displayed on the computer. The measuring device was tested with GE Druck DPI 610 pressure generator.

Results: Test results showed that the device has a sensitivity of $0.01 \mathrm{kPa}$, measuring range from 0.1 to $10 \mathrm{kPa}$ and an accuracy of $0.01 \mathrm{kPa}$.

Conclusion: This measurement system is important for objectively assessing the pressure of the bra on the wearer.

Originality: This paper presents the results of research and design of the PB228 system when measuring the pressure of the bra on the wearer's body in static, dynamic and static-dynamic combined states.

Limitations: The accuracy of the device only applies in standard conditions.

Keywords: Bra, bra pressure, air pressure sensor, pressure measuring device.

\section{Resumen}

Introducción: este documento es el resultado de la investigación "Desarrollo del sistema de medición de presión de sostén utilizando aire sensor de presión "desarrollado en la Universidad de Ciencia y Tecnología de Ha Noi en 2019.

Problema: la presión del sostén sobre el cuerpo humano afecta la comodidad del usuario y la salud del usuario. Por lo tanto, la presión del sostén es uno de los parámetros más importantes que se tienen en cuenta al diseñar y fabricar brasieres.

Objetivo: Para determinar el valor de presión de un sujetador, es necesario usar un dispositivo de medición de presión adecuado.

Metodología: el dispositivo funciona según el principio del sensor de presión de gas resistente, con 8 canales de medición. El sistema es controlado por la computadora a través del software de programación en el lenguaje Visual C, midiendo la presión de la camisa sobre la posición en la superficie curva del cuerpo humano. Valores de presión y gráficos cronometrados se muestran en la computadora. El dispositivo de medición se probó con el generador de presión GE Druck DPI 610.

Resultados: Los resultados de la prueba mostraron que el dispositivo tiene una sensibilidad de $0.01 \mathrm{kPa}$, rango de medición de 0.1 a $10 \mathrm{kPa}$ y una precisión de $0.01 \mathrm{kPa}$.

Conclusión: este sistema de medición es importante para evaluar objetivamente la presión del sostén sobre el portador

Originalidad: este documento presenta los resultados de la investigación y el diseño del sistema PB228 al medir presión del sujetador sobre el cuerpo del usuario en estados combinados estático, dinámico y estático-dinámico. Limitaciones: la precisión del dispositivo solo se aplica en condiciones estándar.

Palabras clave: sujetador, presión del sujetador, sensor de presión de aire, dispositivo de medición de presión 


\section{Resumo}

Introdução: este documento é o resultado da pesquisa "Desenvolvimento do sistema de medição de pressão de suporte usando ar sensor de pressão "desenvolvido na Universidade de Ciência e Tecnologia Ha Noi em 2019.

Problema: a pressão do sutiã no corpo humano afeta o conforto do usuário e a saúde do usuário. Portanto, a pressão do suporte é um dos parâmetros mais importantes que são levados em consideração ao projetar e fazer sutiãs.

Objetivo: Para determinar o valor da pressão de um fixador, é necessário usar um dispositivo de medição de pressão adequado.

Metodologia: o dispositivo funciona de acordo com o princípio do sensor de pressão de gás resistente, com 8 canais de medição. 0 sistema é controlado pelo computador através do software de programação na linguagem Visual C, medindo a pressão da camisa sobre a posição na superfície curva do corpo humano. Valores de pressão e gráficos temporizados Eles são exibidos no computador. O dispositivo de medição foi testado com o gerador de pressão GE Druck DPI 610.

Resultados: os resultados do teste mostraram que o dispositivo possui uma sensibilidade de 0,01 kPa, faixa de medição de 0,1 a $10 \mathrm{kPa}$ e uma precisão de 0,01 kPa.

Conclusão: este sistema de medição é importante para avaliar objetivamente a pressão do suporte no transportadora

Originalidade: Este documento apresenta os resultados da pesquisa e projeto do sistema PB228 ao medir pressão do prendedor no corpo do usuário em estados estáticos, dinâmicos e estático-dinâmicos combinados.

Limitações: a precisão do dispositivo se aplica somente em condições padrão.

Palavras-chave: fixador, pressão do fixador, sensor de pressão do ar, dispositivo de medição de pressão

\section{INTRODUCTION}

Pressure on the bra is one of the most important factors affecting the wearer's health. Pressure on the bra can cause the wearer discomfort, blood flow reduction or aches if the pressure value is greater than the human's tolerance. The device to measure the pressure of a bra on a wearer's body is necessary to perform studies of comfort pressure to help designers and producers create fitting bra products to avoid injury to the body.

There are now a number of devices used to measure the pressure of the bra on the wearer's body. The sensor system of Novel Pliance has been used to measure the static pressure of the bra with 2 sensors [1]. Li-Zhuo Wang and colleagues used the surface contact system of type Ami-3037S- 5 to measure the pressure distribution on the bra [2], and points on the bra edge [3]. This airbag sensor system is made with a sealed, thin, soft, sealed bag [4], and calibrated by the water column method [5] measuring the pressure of the bra in different positions.

AMI 3037 pressure measuring device of AMI Techno Co. Ltd Japan uses a sensor that is $20 \mathrm{~mm}$ in diameter and $1 \mathrm{~mm}$ in thickness, measuring from 0 to 34 
$\mathrm{kPa}$, within $\pm 0.03 \mathrm{kPa}[6,7]$. This system has 10 probes for measuring the pressure of tight clothing on the human body, but the device is expensive and the manufacturer only provides complete equipment. Furthermore, this device only applies to an item of clothing's pressure measurement in a stationary state.

Research on the effect of breast shape and the type of bra on the wearer's comfort is also performed by the Ami 3037 measuring system on the bra in a stationary state [8].

Xiaomeng Liang used a handheld device with a measuring head to measure the pressure on the bra [9]. The Flexciforce sensor was also used by Guo Mengna1 and colleagues when measuring the pressure on the skirt [10]. Nguyen Quoc Toan et al designed devices using Flexciforce sensors to measure costume pressure [11]. However, the Plexciforce sensor is limited when measuring the pressure of the bra due to the curved surface of the body and the measurement range is not suitable.

Phan Thanh Thao et al [12] have designed and built a handheld device that measures the pressure of the costume on the body using MPX10DP gas pressure sensors. This device can measure bra pressure in static mode with 4 gauges.

Mesuring the pressure value on the bra requires a device with high sensitivity, accuracy and stability. The sensor must be human-friendly and be able to measure the pressure in positions on the curved surface of the human body. In particular, the device must be able to measure the pressure values of the bra simultaneously in different states. This paper presents the results of designing and manufacturing the PB228 bra pressure measuring system. Measuring equipment is controlled by computer with automatic data acquisition software. This system is capable of measuring pressure values simultaneously in a static, dynamic and combined state, displaying the value and pressure chart over time using 8 sensors during the measurement process.

\section{CONTENT AND RESEARCH METHODS}

\subsection{Set up pressure measuring system for bra using air pressure sensor}

\section{Principle of operation of the measuring system}

The PB228 pressure measuring system operates on the principle of resistive gas pressure sensor. 8 airbags are placed in 8 contact positions between the shirt and the body. The compressive force from the bra on the air bag (1) passes through the air 
duct (2) and is directed to the pressure sensor (3). The obtained pressure will be transmitted through an INA118P (4) amplifier to obtain voltage signals in the measuring range. These voltage signals will be transmitted to the Arduino Mega2560 R3 (5) for processing. Pressure values and a chart of the system are displayed on the computer screen (6) through software written in the Visual C language (Figure 1).

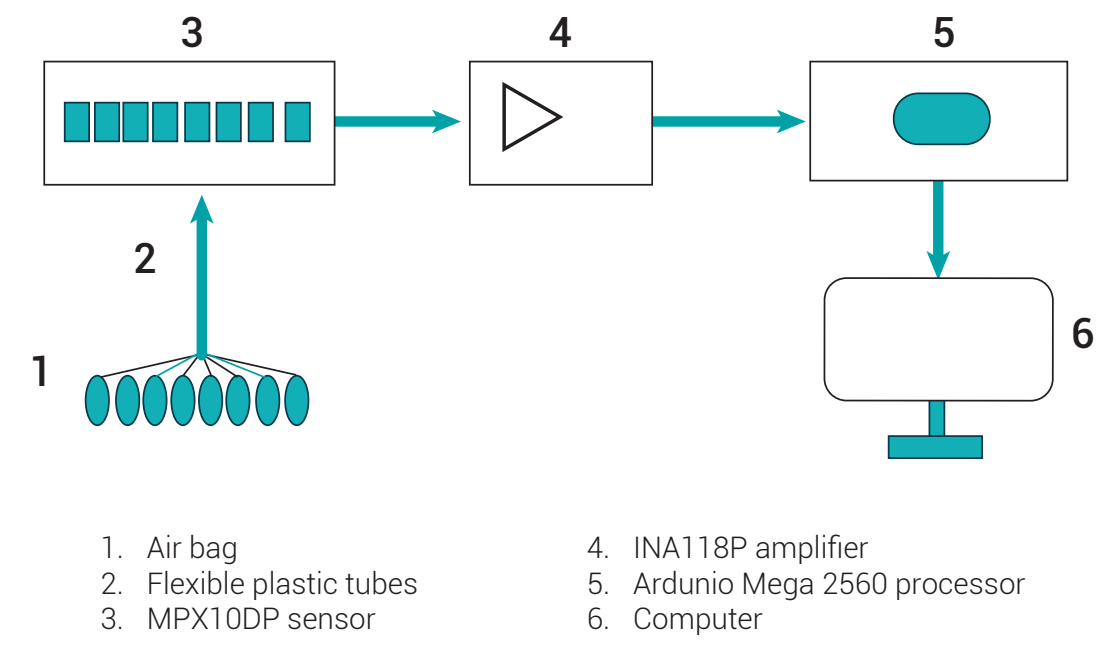

Figure 1. Diagram of pressure measuring system block Source: own work

\section{The structure of the bra pressure measurement system}

The structure of the PB228 pressure measuring system is shown in Figure 2. Airbags are manufactured with length $\times$ width $\times$ height $=35 \times 25 \times 20(\mathrm{~mm})$. Air bags made of polyethylene are soft, thin, non-elastic and user-friendly. Tough, durable airbags during use, are sealed, keeping a stable amount of gas within during measurement. The air bag is connected to the pressure sensor with a non-expandable plastic air duct, the $6 \mathrm{~mm}$ diameter corresponds to the air hole diameter of the MXP10DP sensor. The length of each air duct is $1200 \mathrm{~mm}$ to ensure that the measured person can perform the posture and movement within the allowable range.

A MPX10DP sensor is used to measure the pressure transfered from the airbag. Measuring range is from 0 to $10 \mathrm{kPa}$ with a sensitivity of $3.5 \mathrm{mV} / \mathrm{kPa}$. Because the input voltage is small, the INA118P amplifier circuit should be used. Since the operation of the MPX10DP sensor depends on the external temperature, the system will perform pressure measurement under standard conditions of $(25 \pm 2)^{\circ} \mathrm{C}$ and humidity of $(65 \pm$ 2)\%. Received signals are processed via Ardunio Mega 2560 R3 IC. 

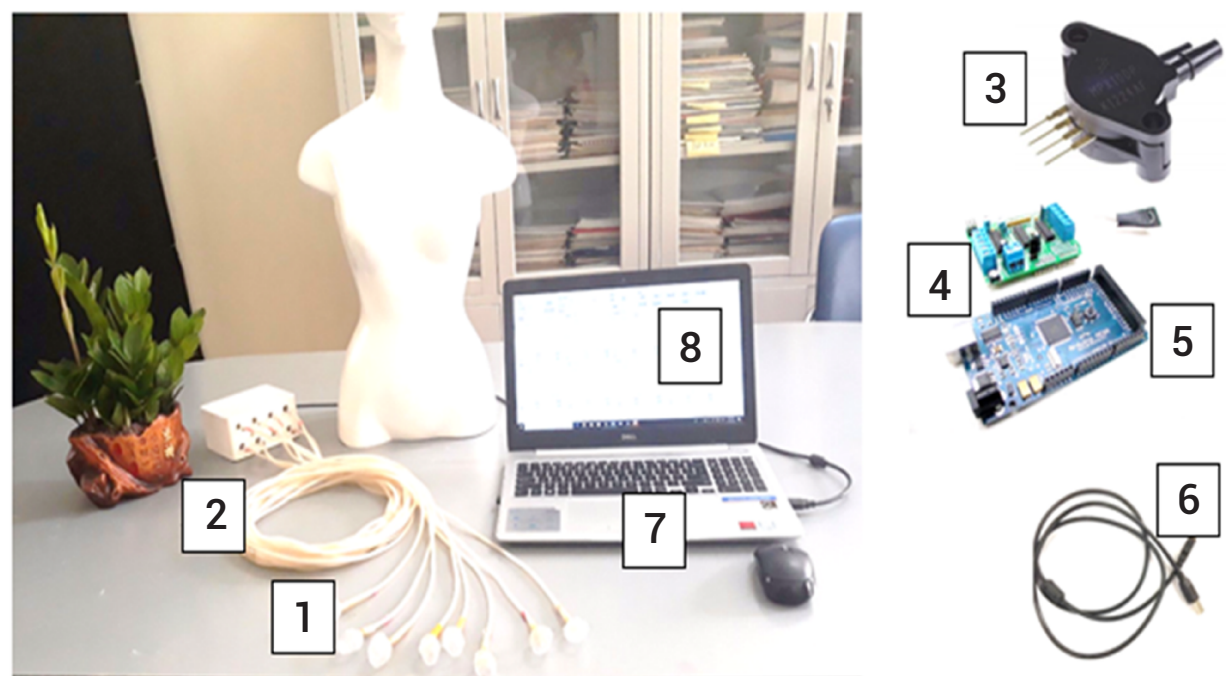

1. Air bag

2. Air duct

3. MPX10DP pressure sensor

4. INA118P implifier circuit
5. Ardunio Mega2560 signal processing circuit 6. Power cord

7. Computer

8. Software

Figure 2. Structure of PB228 pressure measuring system Source: own work

\section{Interface and function of measurement control software.}

Bra pressure control software programmed in the Visual $\mathrm{C}$ language is installed on the computer that is connected to the measuring device via USB port, allowing static and dynamic measurements to be performed. The system automatically extracts the measurement results and graphs the pressure over time for each sensor. Each display box corresponds to a pressure measuring channel. The measured object information, measurement sample and measurement time are displayed in the interface. Pressure values are automatically recorded after $0.2 \mathrm{~s}$ for dynamic measurements and $2 \mathrm{~s}$ for static measurements. The interface of the measurement control software is shown in Figure 3. The information of the measurement object, the sample, the measurement time and the graphs are displayed in the interface. The interface consists of 8 boxes corresponding to 8 pressure measurement channels. The system measures the pressure simultaneously or separately for each channel. 
Hong Nhung Luu Thi, Trinh Nguyen Nhat, Linh Nguyen Thi Dieu, Le Nguyen Thi 7

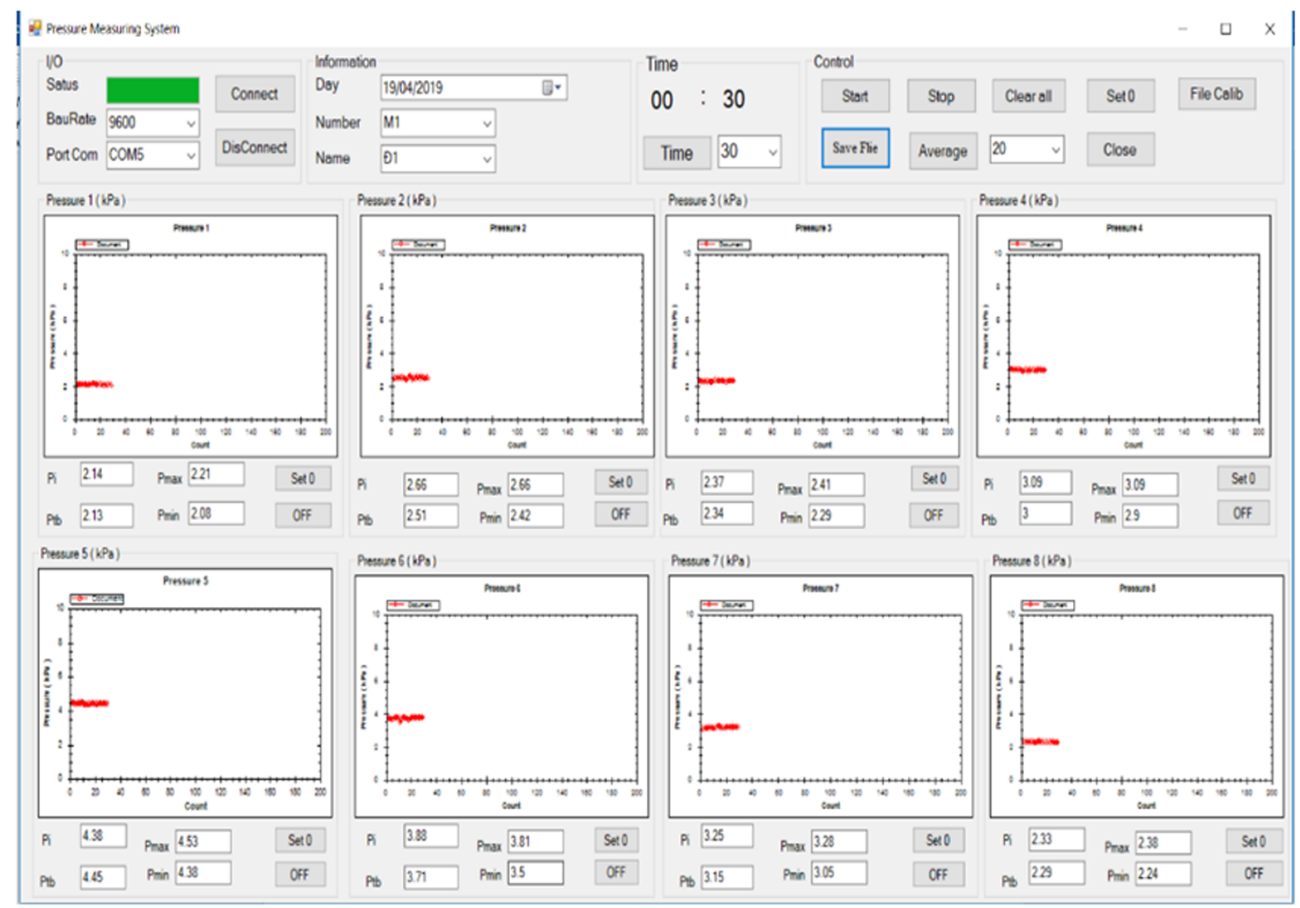

Figure 3. Interface for measurement control software. Source: own work

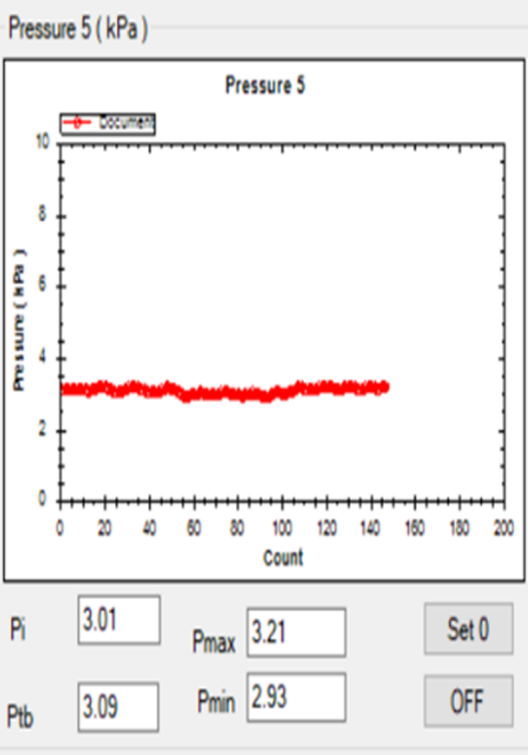

(a)

\begin{tabular}{|c|c|c|c|c|c|c|c|c|}
\hline \multicolumn{7}{|c|}{ PRESSURE VALUE AT THE SENSOR } \\
\hline Count & Pressure 1 & Pressure 2 & Pressure 3 & Pressure 4 & Pressure 5 & Pressure 6 & Pressure 7 & Pressure 8 \\
\hline 1 & 2,88 & 2,96 & 3,93 & 4,2 & 4,36 & 2,39 & 2,95 & 2,9 \\
\hline 2 & 2,8 & 2,92 & 3,91 & 4,17 & 4,36 & 2,32 & 2,89 & 2,84 \\
\hline 3 & 2,84 & 2,98 & 4,02 & 4,26 & 4,51 & 2,45 & 2,93 & 2,87 \\
\hline 4 & 2,76 & 2,9 & 3,91 & 4,2 & 4,28 & 2,29 & 2,87 & 2,79 \\
\hline 5 & 2,76 & 2,9 & 3,87 & 4,17 & 4,23 & 2,27 & 2,87 & 2,79 \\
\hline 6 & 2,82 & 2,94 & 3,93 & 4,15 & 4,29 & 2,34 & 2,89 & 2,84 \\
\hline 7 & 2,78 & 2,87 & 3,87 & 4,17 & 4,29 & 2,25 & 2,85 & 2,79 \\
\hline 8 & 2,82 & 2,96 & 3,95 & 4,17 & 4,36 & 2,36 & 2,91 & 2,85 \\
\hline 9 & 2,78 & 2,9 & 3,91 & 4,17 & 4,28 & 2,29 & 2,87 & 2,81 \\
\hline 10 & 2,76 & 2,87 & 3,89 & 4,17 & 4,26 & 2,25 & 2,85 & 2,77 \\
\hline 11 & 2,82 & 2,96 & 3,97 & 4,13 & 4,34 & 2,36 & 2,91 & 2,85 \\
\hline 12 & 2,78 & 2,92 & 3,93 & 4,2 & 4,36 & 2,34 & 2,87 & 2,84 \\
\hline 13 & 2,84 & 3,03 & 4,2 & 4,41 & 4,85 & 2,66 & 2,95 & 3,03 \\
\hline 14 & 2,8 & 2,96 & 4,1 & 4,36 & 4,73 & 2,52 & 2,87 & 2,9 \\
\hline 15 & 2,71 & 2,87 & 3,93 & 4,23 & 4,38 & 2,39 & 2,83 & 2,84 \\
\hline 16 & 2,74 & 2,87 & 3,91 & 4,13 & 4,28 & 2,29 & 2,83 & 2,79 \\
\hline 17 & 2,8 & 2,96 & 4,03 & 4,17 & 4,4 & 2,43 & 2,89 & 2,92 \\
\hline 18 & 2,74 & 2,87 & 3,93 & 4,09 & 4,26 & 2,32 & 2,85 & 2,84 \\
\hline 19 & 2,76 & 2,87 & 3,91 & 4,07 & 4,28 & 2,29 & 2,83 & 2,81 \\
\hline 20 & 2,8 & 2,96 & 4,03 & 4,13 & 4,4 & 2,47 & 2,89 & 2,92 \\
\hline 21 & 2,76 & 2,9 & 3,93 & 4,07 & 4,26 & 2,32 & 2,85 & 2,81 \\
\hline 22 & 2,74 & 2,85 & 3,89 & 4,02 & 4,23 & 2,25 & 2,81 & 2,79 \\
\hline 23 & 2,82 & 2,96 & 4,08 & 4,04 & 4,42 & 2,43 & 2,89 & 2,87 \\
\hline 24 & 2,76 & 2,92 & 3,95 & 4,02 & 4,23 & 2,36 & 2,85 & 2,84 \\
\hline 25 & 2,71 & 2,85 & 3,87 & 4,02 & 4,2 & 2,2 & 2,79 & 2,77 \\
\hline 26 & 2,76 & 2,92 & 3,95 & 4,04 & 4,29 & 2,34 & 2,85 & 2,85 \\
\hline & & & & & & & & \\
\hline
\end{tabular}

(b)

Figure 4. Measurement data in graph form (a) and text format (b)

Source: own work 


\subsection{System calibration}

The GE Druck DPI 610 pressure pump is used to calibrate the measuring device (Figure 5). Take a piece of wire tube of the same type with the wire tube connected to the air bag with a length of about $200 \mathrm{~mm}$. Attach one end of this wire tube to the output end of the DPI 610 pressure pump; the other end is connected to a sensor. The sensor of the connected measuring system is displayed on the computer. The scope of the pressure survey of the bra is in the range of 0 to $10 \mathrm{kPa}$, so the amount of air is pumped into the pressure pump is from 2 to $10 \mathrm{kPa}$. Pressure values are displayed on the GE Druck DPI 610 device and software on the computer. The measurement is repeated 3 times with each sensor.

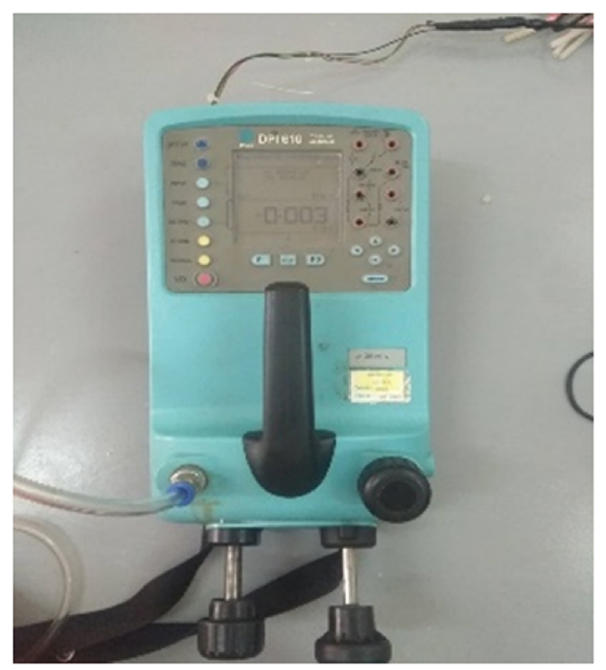

Figure 5. GE Druck DPI 610 calibration device Source: own work

To calculate the experimental error, select the evaluation domain $\Delta \mathrm{h}=0.01 \mathrm{bar}$ corresponding to $1 \mathrm{kPa}$; each pressure value is measured 3 times at the sensors. Test results of pressure measurement on the DPI 610 calibration equipment and the PB228 pressure measuring device as shown in Figure 6. 


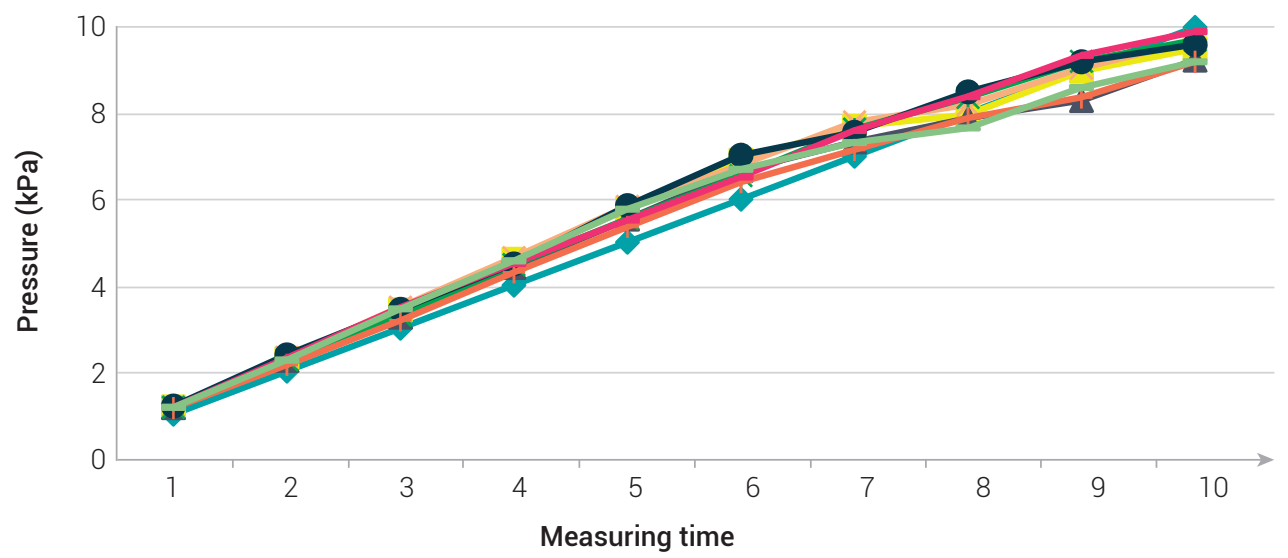

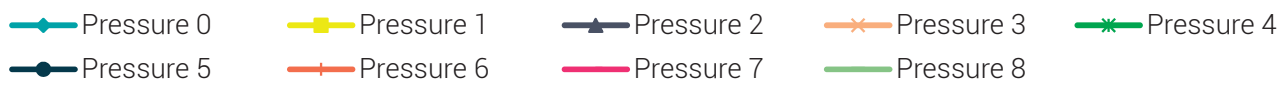

Figure 6. The pressure value comparison of PB228 system compared to standard test equipment

Source: own work

The pressure value of the calibration device is shown in the zero sensor. Pressure values of the PB228 measuring system is from sensor 1 to sensor 8 . Generally, the pressure values of the measuring system are equal to or higher than the standard test equipment 0.15 to $0.5 \mathrm{kPa}$. When compared with a calibration device, the pressure value of PB228 pressure measuring device is measured from 0 to $8 \mathrm{kPa}$ because this is the measurement range that ensures the equipment's requirements. In this measurement range the pressure value is relatively stable and adheres to the standard value. Over $8 \mathrm{kPa}$ the pressure values between the sensors has a difference of about $0.5 \mathrm{kPa}$.

Evaluation of pressure values of sensors in the PB228 device compared with the GE Druck DPI 610 calibration device are as follows:

$$
x_{i}=\left|a_{i}-b_{i}\right|
$$

$a_{i}$ : pressure value of pressure pump GE Druck DPI $610(\mathrm{kPa})$

$b_{i}$ : pressure value of PB228 device $(\mathrm{kPa})$

$x_{i}$ : difference in pressure between $a_{i}$ and $b_{i}(\mathrm{kPa})$

Average value of $x_{i}: \quad \bar{x}=\frac{\sum_{i=1}^{n} x i}{n}=0.4 \quad(\mathrm{kPa})$

$n$ : number of pressure measurements.

$\bar{x}$ : Average value number of $x$ 
The uncertainty values are calculated using the following equation:

$$
u_{(A)}=f(n) s_{\bar{x}}=f(n) \sqrt{\frac{\sum_{i=1}^{n}\left(x_{i}-\bar{x}\right)^{2}}{n(n-1)}}=0.011(\mathrm{kPa})
$$

Where $n$ is the measurement number, $x_{i}$ is the measured data, $f(n)$ is associated with the confidence factor (generally taken as 1 on the line), and $S$ is the standard deviation of the average.

Data illustrates that the test results of the proposed system are accurate and efficient at measuring by comparison with the experimental micrometer. The errors of the measured values fluctuated within the range, which indicates the stability and reliability of the compared system.

\subsection{Resolution}

The required measuring range of equipment lies between 0 to $10 \mathrm{kPa}$. The MPX10DP gas pressure sensor has a sensitivity of $3.5 \mathrm{mV} / \mathrm{kPa}$ [11]. Within the maximum limit of $10 \mathrm{kPa}$, the voltage obtained from MPX10DP is $35 \mathrm{mV}$. The ADC input voltage range of the Arduino Mega2560 microcontroller is 0 to $5 \mathrm{~V}$ corresponding to the resolution $2^{10}=1024$.

The gain coefficient of the input voltage of the Arduino and the output of the MPX10DP sensor are selected $K=140$ implemented by INA algorithm amplifier.

The maximum voltage applied to the ADC corresponding to the maximum measuring pressure of $10 \mathrm{kPa}$ is $4.9 \mathrm{~V}$.

Resolution of the measuring system:

$$
\frac{U \max }{a}=0.0097 \mathrm{kPa} \sim 0.01 \mathrm{kPa}
$$

Umax: Maximum voltage of the MPX10DP sensor.

$a$ : Resolution level of the Arduino Mega2560

\subsection{Experimental design}

To assess the device's ability to measure the pressure of the bra, the tests are measured in standard drainage conditions $t^{0}=25 \pm 2^{\circ}$, humidity $65 \pm 2 \%$. The air bag is placed in the contact position between the shirt and the human body at the selected points so that the force acts on the middle of the air bag. The measuring object 
remains in a predetermined position for at least 30 seconds in a static state. The measured woman wears the bra with short hair or high bun.

The pressure of the bra is assessed at 8 important points (Figure 7) related to the design process, testing the object on a 33-year-old female, $1 \mathrm{~m} 55$ tall, weighing 60 kg, using a Tikinow firm bra cushion cup.

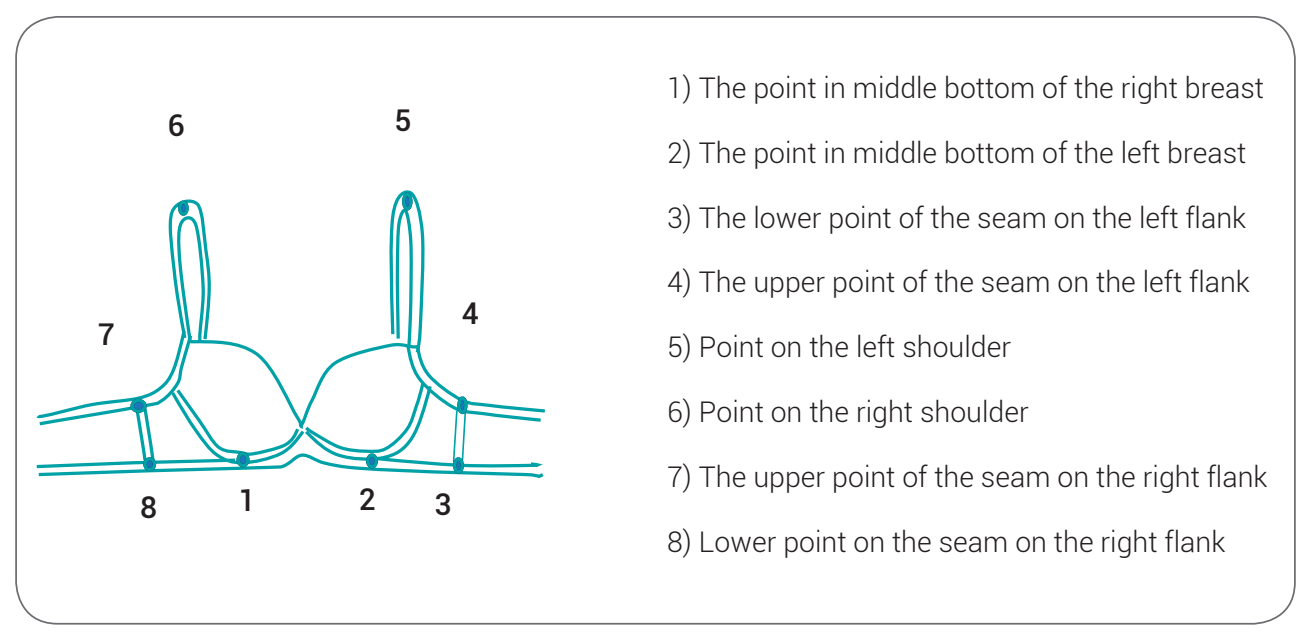

Figure 7. The position of the pressure sensors on the bra

Source: own work

The PB228 system is used to measure simultaneous pressure values at 8 points on the bra in static, dynamic and combined static-dynamic states.

For the static state, the measured person wears a bra standing in 3 positions: standing upright, two hands placed down by her sides; stood up straight with her hands high and stood up straight with his hands in front of her. Static measurement mode is selected on the computer and pressure measurements are performed over 30 seconds. 

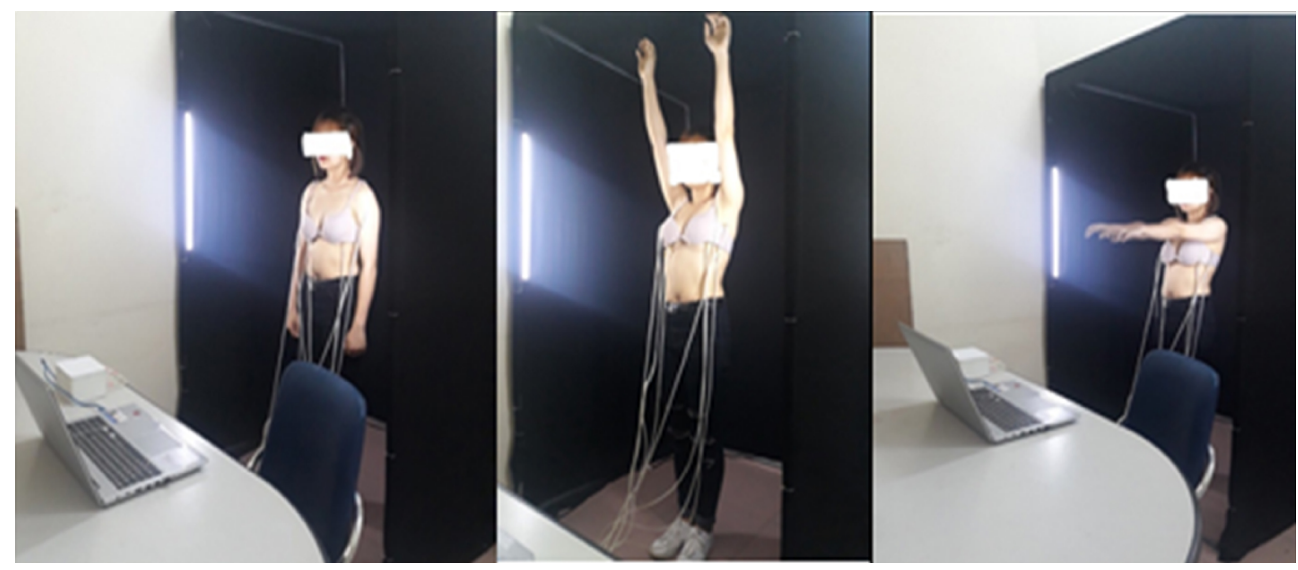

Figure 8. The static postures used while measuring the bra pressure Source: own work

As for the combined static-dynamic state, the bra-wearing person performed short activities - raising her hand in front of her face - raised her hand and stood still sitting on the chair - bending down to tie her shoes. During the period of 30 seconds, each activity takes place over 10 seconds, monitoring pressure changes at 8 points on the bra. Pressure values were observed and evaluated on the computer.

For the dynamic state, the airbag sensors were placed at the 8 selected positions on the subject's bra, using medical tape to keep the sensors fixed on the body. The software was switched to dynamic measurement mode and the subject wearing the bra runs on the spot. The measured pressure value of 8 sensors in this operation was shown on the computer screen.

\section{RESULTS AND DISCUSSION}

\subsection{Stability of the device}

To assess the stability of the PB228 system over time, the pressure of the bra is measured at the same point in the time periods: 5 s, 10s, 15s, 20s, 25s, 30s, 35s, 40s. With position 2 selected - the point at the bottom of the left breast is the survey point. The pressure measurement results of the 8 sensors at each time point are shown in Figure 9. 


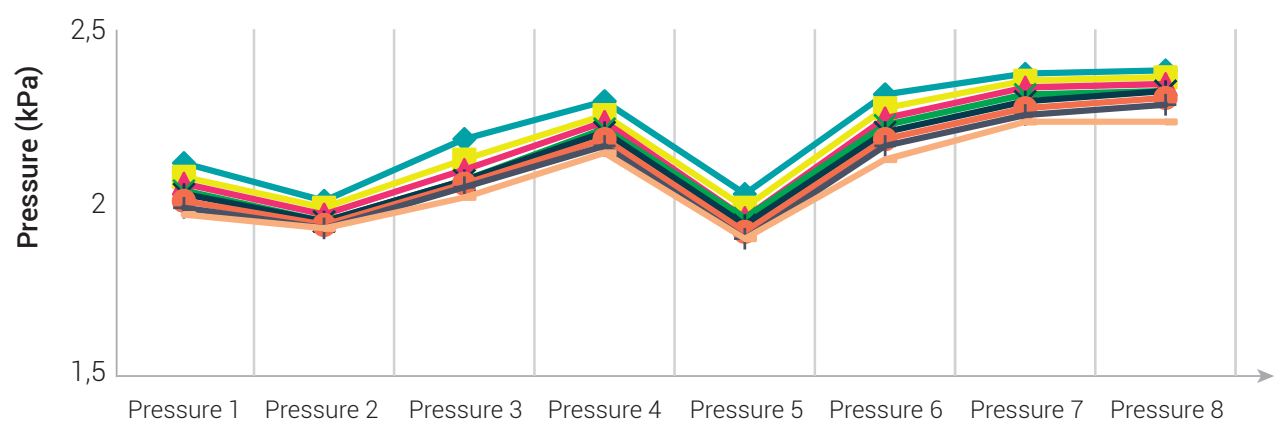

\section{Sensor}

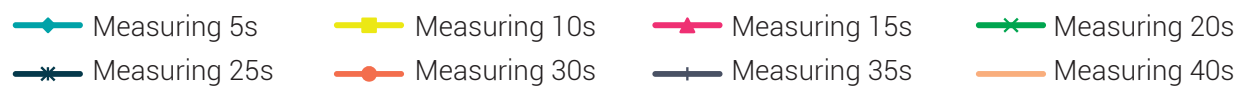

Figure 9. Measuring 8 sensor values at position 2 from $5 \mathrm{~s}$ to $40 \mathrm{~s}$

Source: own work

The pressure of the chest between the sensors measured at position 2 is determined at the time points selected for the value difference, oscillating in the range of $0.4 \mathrm{kPa}$. Pressure values at the sensors are quite stable over the measurements. At each time interval of $5 \mathrm{~s}$, the pressure value decreased by $0.02 \mathrm{kPa}$. Therefore, to achieve high accuracy when measuring bra pressure, it is recommended to select the same measurement period.

To examine the pressure difference between the eight measurement channels of the system, each measurement channel must be tested in the same position of any bra when being worn on a mannequin. Position number 2 - the middle bottom point of the left breast is selected to calibrate the sensor. The measuring objects in this case is the mannequin, to limit the impact of external effects such as vibration or position deviation when moving. Each measurement channel performs the measurement 10 times at that specified location.

Pressure values of the 8 channels, when measured at the same position on the bra, ranged from 3.26 to $3.307 \mathrm{kPa}$. The error between 8 measuring channels is 0.04 $\mathrm{kPa}$. Thus, the pressure value obtained between the measuring channels lies within the allowed range. The system can completely use 8 measuring channels to examine the pressure of the bra simultaneously at 8 positions on the bra. 


\subsection{The results of measuring pressure values of the bra on the wearer}

\section{Measuring the bra pressure in the static state.}

Results of pressure values of the chest in 3 positions: standing upright with two hands placed down by her sides, standing upright with both hands raised high above the head and standing upright with hands held out in front are shown in Figure 10. The measured pressure values from the PB228 measuring system show that the bra pressure in the different postures is not the same.

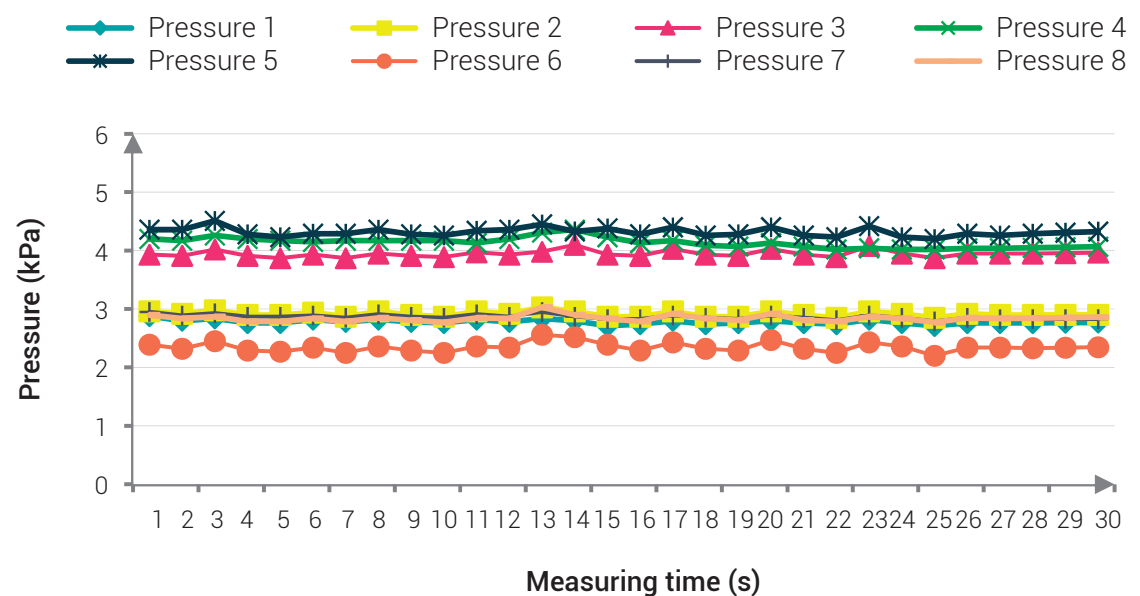

a. The pressure values of bra in upright position

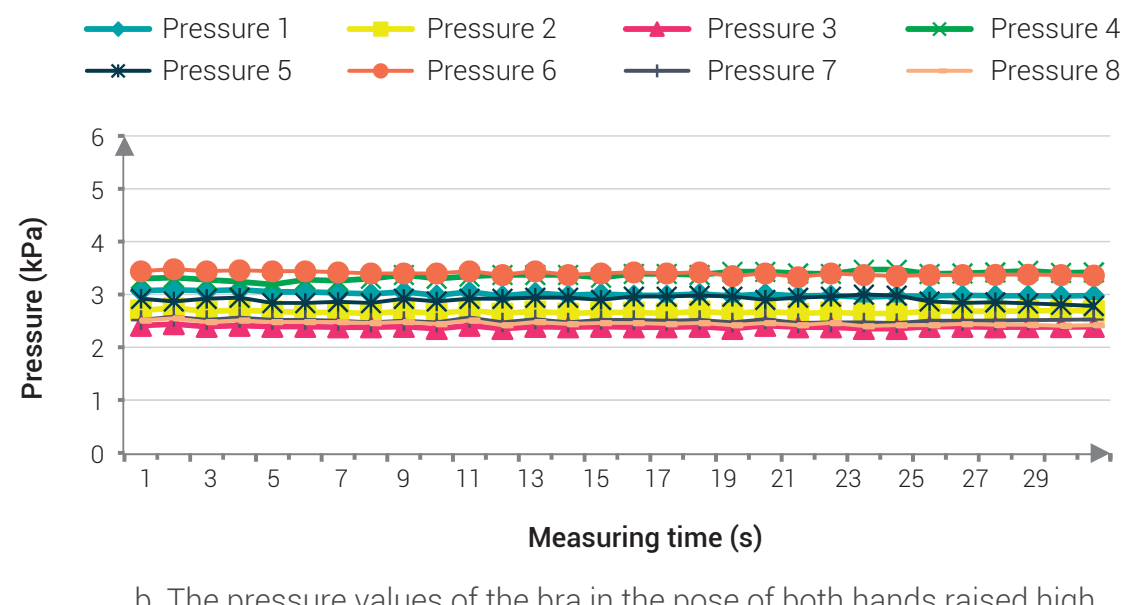




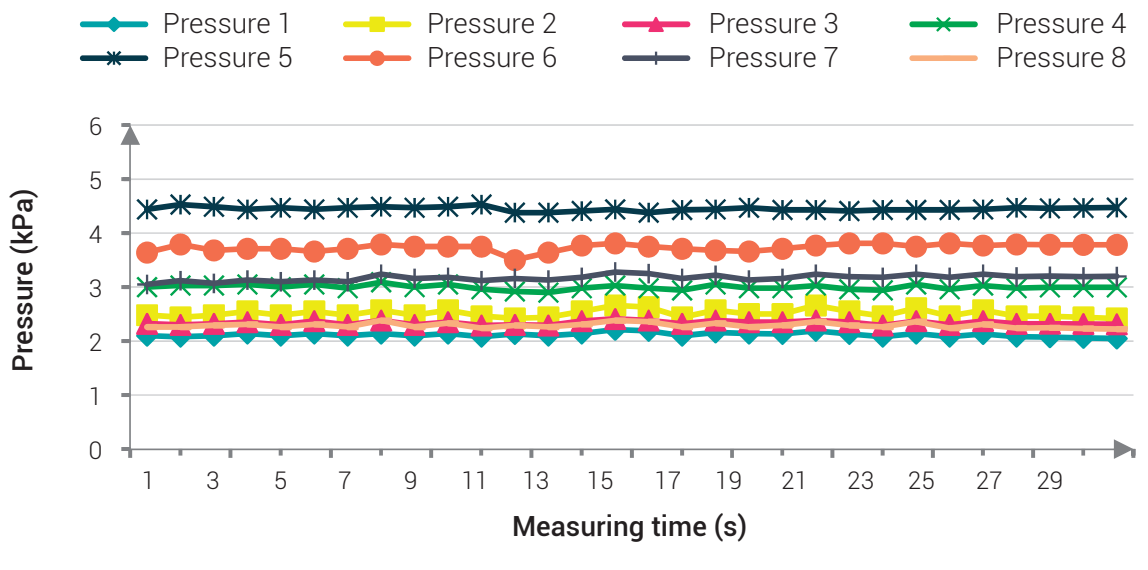

c. The pressure values of the bra in the pose with hands held out in front

Figure 10. Pressure distribution of static bra Source: own work

Pressure values at the 8 sensors are very stable over a period of 30 seconds, each position has different pressure values. In the upright position, the highest pressure value is $4.5 \mathrm{kPa}$ at sensor positions 2, 4, 5 and the lowest is the pressure value at position 7 with a pressure of $2.2 \mathrm{kPa}$. For the posture of raising both hands up, the highest pressure value is at positions 4, 6 and the lowest is at sensors 3,8 . Position number 5 and number 6 are on the shoulder but the pressure value is not the same. When raising your hand in front of the body, the pressure value changes. The pressure at 5,6 is the highest and lowest at the $1^{\text {st }}$ position. Thus, the pressure value of the bra is influenced by the standing postures and changes when the posture changes. Pressure values range from 2.52 to $4.85 \mathrm{kPa}$. These values are useful for assessing the comfort of the wearer's bra, thereby building the basis for the design and production of the bra.

\section{Measuring the bra pressure in the static-dynamic combined state.}

Testing of pressures in the standing state - raising the hand in front - raising the hand high continuously during the measurement time of 30s, with each state 10 s, the value of the chest pressure between the measurement positions changes. Each sensor corresponds to the pressure value at a specified measuring point. In this static-dynamic state, the maximum pressure difference between the sensors is $2.01 \mathrm{kPa}$, the minimum pressure value at position 8 is $1.71 \mathrm{kPa}$ and the largest, at position 6, is 4.64 $\mathrm{kPa}$. The maximum pressure difference at one position on the bra is $1.29 \mathrm{kPa}$. Thus, 
the pressure value in the working postures is different. When assessing the pressure of the bra, it is necessary to study the pressure of the bra in different states.

The difference in bra pressure of the sensors is shown in Figure 11.

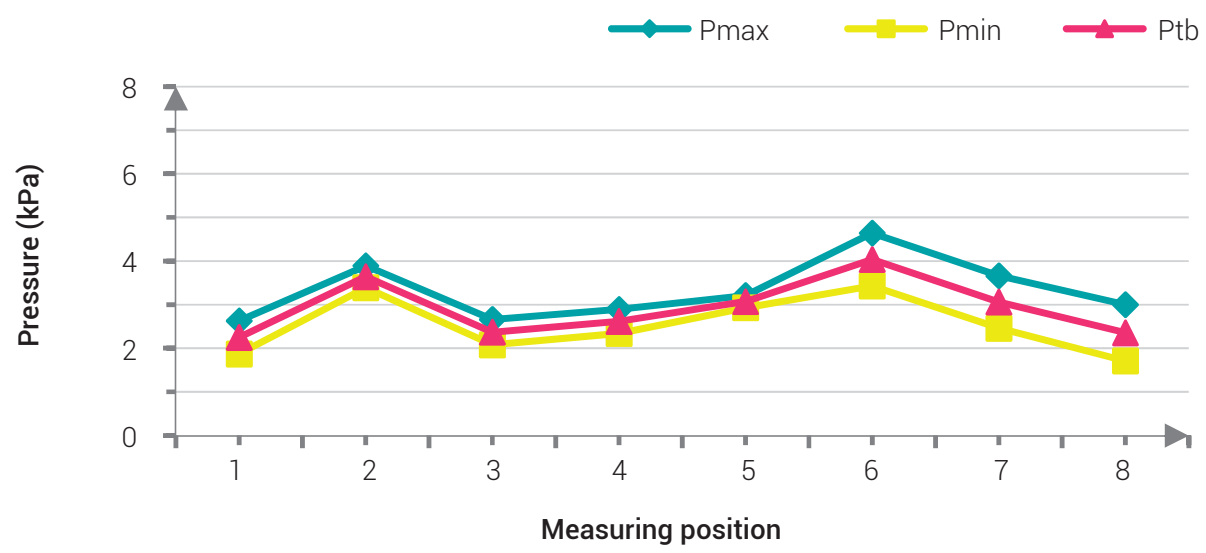

Figure 11. The pressure on the positions of the bra in the state of standing still - raising hand in front and then high

Source: own work

The highest pressure value at position 6 on the left shoulder is $4.7 \mathrm{kPa}$. The pressure on the right shoulder is $3.2 \mathrm{kPa}$. So at the two positions on the shoulder, the pressure value can vary by $1.5 \mathrm{kPa}$. The reason for this difference is due to the deflection of the cup and the belt. Therefore, when examining the value of bra pressure, it is necessary to check the symmetrical points on the shirt.

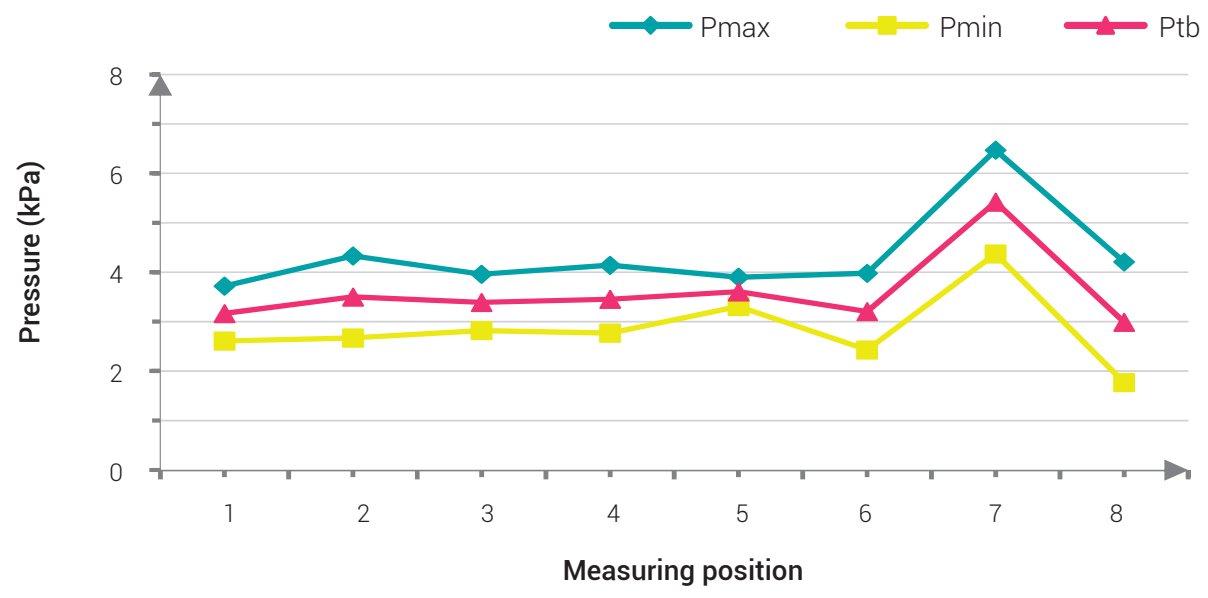

Figure 12. Pressure values in standing states - sitting on chairs - bending down to tie shoes.

Source: own work 
During the 30s period, the value of bra pressure at 8 points is measured in 3 states of standing still, sitting down on the chair, bending down to tie shoes. Sensors 7 and 8 have a differential pressure value greater than $2 \mathrm{kPa}$. The minimum sensor of 5 has a differential pressure of only $0.5 \mathrm{kPa}$.

In the posture of bending down to tie the shoelace, the pressure value of sensor 7 rapidly increase to $6.47 \mathrm{kPa}$, a difference of $2.1 \mathrm{kPa}$ compared to the initial stand still posture. The minimum pressure is at sensor position 8 with a value of $1.77 \mathrm{kPa}$ and with a difference of $2.44 \mathrm{kPa}$ compared to the original posture. With the same person wearing the bra but in an active state with different postures, the pressure values of the bra also change. In a bowing posture, tying the shoelace also adds a pressure of the body to the chest so the pressure on the bra increases. Therefore, the study of the value of bra pressure in different poses is necessary for the design of appropriate bra.

\section{Measuring the bra pressure in dynamic state}

The PB228 system can measure the pressure values of the bra when running on the spot for 30 seconds. The change of bra pressure shown on sensors 3, 4 and 7, 8 has a high frequency of oscillation. The maximum pressure value is up to $7 \mathrm{kPa}$. Sensors 1, 2 and 5, 6 have fluctuations but less. The reason is that positions 3, 4 and 7, 8 are at the side of the ribcage and are strongly affected when the hand moves.

The value of the bra pressures when running on the spot are shown in Figure 13.

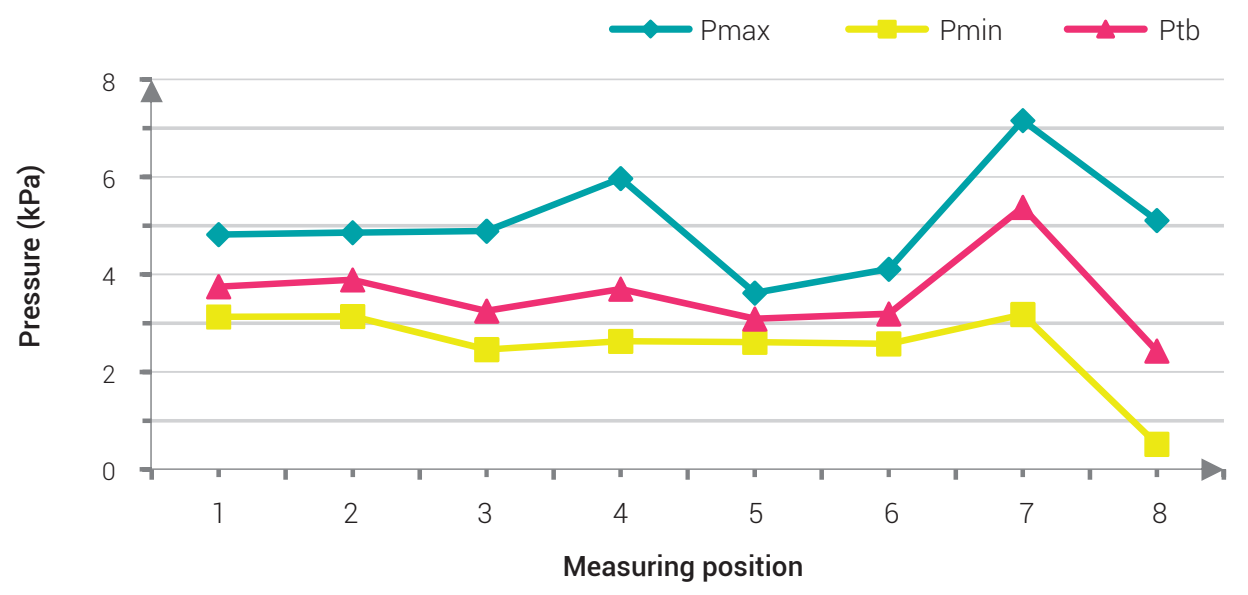

Figure 13. Pressure value when running in place Source: own work 
While running on the spot, the pressure value of the bra varies from 0.52 to 7.16 $\mathrm{kPa}$. The highest pressure value is $7.16 \mathrm{kPa}$ at sensor 7 and the lowest is $0.52 \mathrm{kPa}$ at sensor 8 , demonstratng the strongest fluctuation. In this state, the pressure is repeated periodically (Figure 14). The pressure difference at the highest sensor is $4.59 \mathrm{kPa}$, sensor 7 is $3.98 \mathrm{kPa}$ and sensor 4 is $3.34 \mathrm{kPa}$. The remaining positions with the value of bra pressure vary from 1.01 to $2.43 \mathrm{kPa}$. This means that measuring only pressure in a static state is not enough to assess the comfort of a bra. It is necessary to have research on the pressure of the bra in a dynamic state to evaluate the maximum pressure on the body to help create suitable bra products.

Experimental results show that the PB228 pressure measuring system can measure the pressure values of female bras in different postures and states. The device has 8 probes that allow the pressure value to be obtained at 8 positions simultaneously and quickly, with the error between the sensors of $0.4 \mathrm{kPa}$, measuring range of 0.1 to $10 \mathrm{kPa} \pm 0.1 \mathrm{kPa}$, consistent with the value of bra pressure of some other studies [6]. Air bags ensure the measurement requirements, keeping a stable amount of air, whilst being friendly to human skin. The software displays values and graphs of the pressure over time of each sensor as shown in Figure 14.

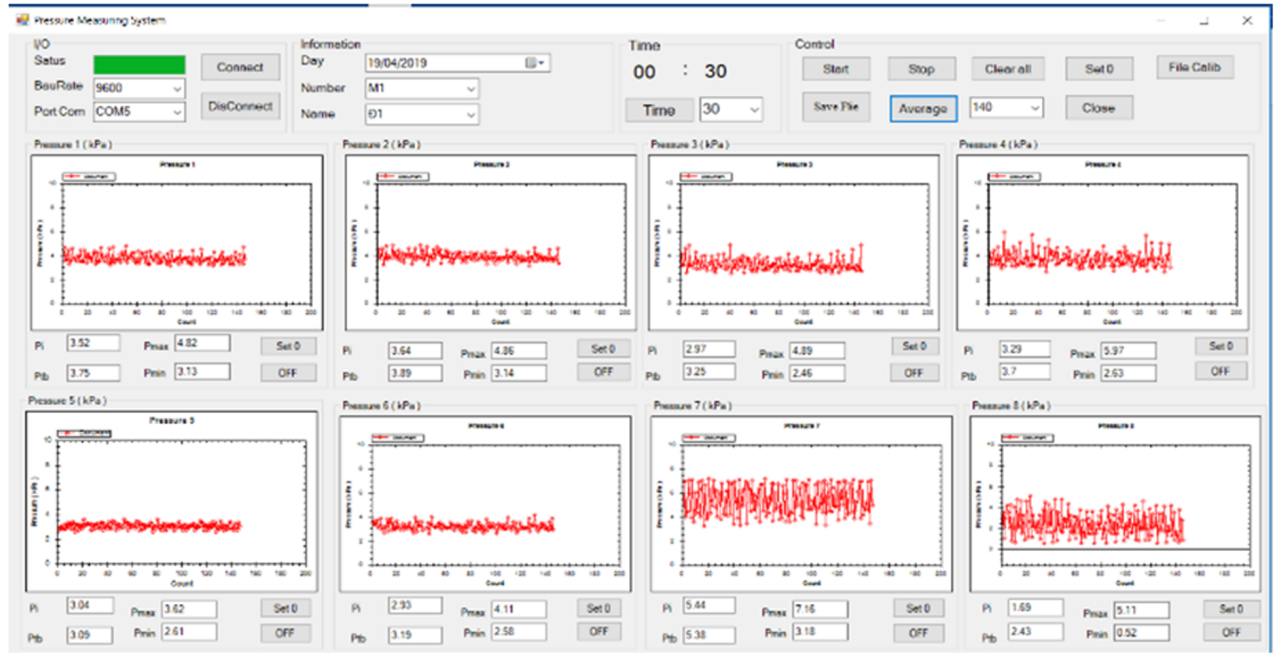

Figure 14. The values of bra pressures over time when running in place. Source: own work

The PB228 pressure measuring system allows simultaneous pressure measurement at 8 positions on the body when wearing a bra. The device is capable of measuring bra pressure in static, dynamic and combined states. 


\section{CONCLUSIONS}

The PB228 bra pressure measuring system has been set up and calibrated to meet the requirements of measuring pressure on the human bra. The system operates on the principle of resistive gas pressure sensors, which are highly sensitive, suitable for measuring the pressure of the bra on the human body. The system is capable of measuring pressure values in the range of $0-8 \mathrm{kPa}$. The error between sensors is negligible.

The measuring system is controlled via computer software in the Visual $\mathrm{C}$ language, displaying the value and pressure graphs simultaneously of 8 bra positions. Pressure values at the time of measurement including maximum, medium and minimum pressure values are automatically displayed on the screen for the information collection process. The software is easy to use, allowing for simultaneous or separate measurements in both static and dynamic modes.

The PB228 measuring system has been tested to measure the pressure of the bra in different states. Bra pressure at the specified points lie within the allowed and measured limits of the system. This pressure measuring system can be applied to perform research on the pressure of the bra.

\section{REFERENCES}

[1] Novel, [Online]. Available: www.novel.de.

[2] L.-Z. Wang, D.-S. Chen and B. Lin, "Analysis of Pressure Distribution of Brassiere's Under Wires," Journal of Fiber Bioengineering and Informatics, vol. 2, no. 1. pp. 19-24, 2012.

[3] C. Dongsheng, L. I. U. Hong, Z. Qiaoling and W. Hongge, "Effects of Mechanical Properties of Fabrics on Clothing Pressure," Przeglad Elektrotechniczny, vol. 89, no. 0033-2097. pp. 232$235,2013$.

[4] Y. Komimami, "Air-pack type contact pressure method", U.S. Patent No. 5922.

[5] Y. Komimami, "Contact pressure measurement and a method of calibration", pp. 348-355, 2002.

[6] Ami-Tec, [Online]. Available: http://ami-tec.co.jp/eindex.htm

[7] The Ministry of Economy, Trade and Industry, "Clothing PressureSimulation Technology", That Calculates Clothing Pressure from Fabric TensileStrength Test Results, Toyobo Public Relations Group, pp. 15-20, 2008. 
[8] S. Boo-hyun, Ch. Jin-young, K. Soo-ae, "Clothing Pressure and Subjective Sensations Depending on Breast and Bra Type", p. 2, 2015

[9] L. Xiaomeng, "An Investigation into the pressures and sensations caused by wearing a bra and the influence of these on bra fitting", thesis, De Montfort University, pp. 30-50, 2008.

[10] G. Mengna and V. E. Kuzmichev, "Pressure and comfort perception in the system 'female body-dress," Autex Research Journal, vol. 13, no. 3. pp. 71-78, 2013.

[11] N. Quốc Toản, P. Thanh Thảo, D. Văn Hải, "Thiết kếvà chế tạo thiết bị đo áp lực của trang phục lên cơ thể người sử dụng cảm biến lực," Tạp chí khoa học \& Công nghệ các trường ĐH kỹ thuật, số 110, pp. 132-136, 2016.

[12] P. Thanh Thảo, V. Xuân Hiền, "Thiết kế, chế tạo thiết bị cầm tay đo áp lực của trang phục lên cơ thể người sử dụng cảm biến áp khí MPX10DP," Tạp chí khoa họcvà Công nghệ các trường ĐH kỹ thuật, số 133, pp. 045-052, 2019.

[13] Element, [Online]. Available: https://in.element14.com/nxp/mpx10dp/sensor-diff-press-1 $-45-p s i 344 c / d p / 1457144$ 